\title{
Cidade encantadora é Conceição da Barra
}

\section{Zoziane Bernardo Tolentino ${ }^{1}$}

Cidade encantadora é Conceição da Barra! Localizada ao norte do Espírito Santo e conhecida pelo seu clima tropical, sempre aquece o coração de quem vem da capital. É bastante procurada, tanto pelos capixabas, como pelos mineiros, já que o Espírito Santo faz divisa com o estado de Minas Gerais e atrai turistas do mundo inteiro.

É um destino turístico perfeito para quem quer aproveitar o carnaval. Durante os meses de fevereiro, suas ruas ficam lotadas com o turista e o folião (TEMPORADA LIVRE, 2020) que com uma flechada de cupido sempre certeira, inicia por essa cidade um amor de verão e que quase sempre termina em paixão.

Pode ser apreciada tanto no verão quanto no inverno, pois devido ao seu clima, as águas de suas praias são sempre quentinhas e muito aconchegantes com suas piscininhas. Formações naturais que aprecio desde quando era criancinha.

Apesar da devastação de nossas matas para plantação de monoculturas, temos ainda reservas importantes como a do Riacho Doce no vale do Itaúnas. E não podemos deixar de destacar as unidades de conservação; temos a reserva biológica do Córrego Grande e a Flona do Rio Preto, que com trilhas e lagoas compõem um ambiente perfeito, temos ainda uma Área de Proteção Ambiental e o Parque Estadual de Itaúnas. (IEMA, 2015)

O Parque é o mais visitado do estado, recebendo aproximadamente 100.000 pessoas por ano. Em Itaúnas é possível encontrar a beleza natural das praias, das dunas e da floresta de restinga, além da riqueza histórica de uma vila antiga. (CEPEMAR, 2004)

Soterrada pelas dunas trás um misticismo local, que conta que as areias vieram com uma praga lançada por um padre indignado com uma atitude banal. Agora preste atenção que vem história por aí:

"Diz à lenda que houve uma troca sem satisfação, o padre havia trocado o padroeiro local São Benedito por São Sebastião; revoltado com a situação o povo resolveu dar o troco então, teriam colocado cachaça no lugar do vinho sagrado. O padre não gostando nada dessa atitude, havia rogado uma praga no lugar, que logo após vinha a ser sotterado por banco de areia, onde velha Itaúnas hoje está." (CEPEMAR, 2004).

Acreditar nessa história não é em vão, mas também devemos compreender que devido à falta de vegetação o movimento das dunas causou o soterramento da antiga vila antiga então. Por

1 Bióloga e Fundadora do Coletivo Socioambiental Sementes da Gratidão. E-mail: zozianebernardo@ hotmail.com 
essa razão, ações de manejo nas últimas décadas tentam recuperar a vegetação para conter o avanço das dunas e corrigir tal situação.

A palavra "Itaúnas", que dá nome ao Parque, ao rio e à vila, é de origem tupi-guarani e significa "pedra preta" (ita: pedra e una: preta), nome muito conhecido por ali. Suas manifestações culturais e locais encantam, do Ticumbi ao Alardo, do Jongo ao Reis de Bois, todos querem participar, ninguém deixa para depois, tem também festa de São Sebastião e de São Benedito e a historia dos santos foi resolvida é o que tenho visto. (IEMA, 2015)

Não se pode esquecer o tradicional Festival de Forró, que desde 2001, movimenta vila inteira com sua nação forrozeira. (https://forrodeitaunas.com/festival/)

Conceição da barra, pode até ser pequena, mas possui uma cultura viva e delicada como um poema. Conquista seus visitantes pelas suas peculiaridades, em sua culinária possui a maior moqueca do mundo, prato saboroso e único encontrado em nossa localidade.

Mantém a memória e a resiliência cultural, aqui encontramos quilombos, grandes mantenedores de parte da história de resistência e luta contra escravização local. Santana é um exemplo de quilombo urbano e com as Mulheres de fibras encantam com seu artesanato de fibras de banana.

Nessa cidade tive o privilégio de nascer e só tenho agradecer! Por aqui possuir tanta arte, cultura e lazer!

Como forma de reconhecimento e satisfação, por aqui desenvolvo o projeto socioambiental Sementes da gratidão, sem denominação política partidária ao vinculado a religião, somos um coletivo abertos a ideias da população.

Tendo como norte os ODS da ONU, buscamos um desenvolvimento comunitário significativo, equitativo e justo. Através de ações voluntárias e na busca constante pela colaboração da comunidade, elaboramos ações sociais e ambientais buscando melhorias para sociedade.

Nos envolvemos com, plantio de mudas, limpeza de áreas naturais e arrecadação; fornecimento de ajuda material e humana, essa é nossa missão.

Procuramos estimular, solidariedade, respeito e a compaixão, propondo assim maior valorização da vida e do meio ambiente, através de uma atitude consciente. Com afeto, amor e respeito, esse tem sido nosso jeito de demonstrar com gratidão como é maravilhoso viver em Conceição.

\section{REFERÊNCIASBIBLIOGRÁFICAS}

CEPEMAR - SERVIÇOS DE CONSULTORIA EM MEIO AMBIENTE LTDA (Espírito Santo). Petrobras - Petróleo Brasileiro S.A (org.). PLANO DE MANEJO DO PARQUE ESTADUAL DE ITAÚNAS. Vitória, 2004. Disponível em: https://iema.es.gov.br/PEI. Acesso em: 13 dez. 2020. 
ESPÍRITO SANTO. Instituto do Meio Ambiente e Recursos Hídricos. Governo do Estado do Espírito Santo (org.). Área de Proteção Ambiental de Conceição da Barra. 2015. Disponível em: https://iema.es.gov.br/APA_Conceicao. Acesso em: 22 nov. 2020.

ESPÍRITO SANTO. Parque Estadual de Itaúnas. Instituto do Meio Ambiente e Recursos Hídricos (org.). Parque Estadual de Itaúnas: trilha buraco do bicho e trilha da borboleta. Trilha Buraco do Bicho e Trilha da Borboleta. 2015. Disponível em: https://iema.es.gov.br/PEI. Acesso em: 20 nov. 2020.

FORRÓ de Itaúnas. Disponível em: https://forrodeitaunas.com/festival/. Acesso em: 15 nov. 2020.

TEMPORADA LIVRE LTDA (org.). O que fazer em Conceição da Barra, no Espírito Santo? 2020. Temporada Livre Ltda. Disponível em: https://www.temporadalivre.com/blog/o-quefazer-em-conceicao-da-barra-no-espirito-santo. Acesso em: 22 nov. 2020. 